\title{
Linkages between PISA Results and E-Working
}

\author{
Jozef Hvorecký ${ }^{1}$, Michal Beňo ${ }^{1 *}$ \\ ${ }^{1}$ Institute of Technology and Business in Ceske Budejovice, Ceske Budejovice 370 01, Czech Republic
}

\begin{abstract}
The PISA tests are considered as a quality measurement for education. If it is so, then their high results might influence the proportion between blue and white collars. As the intellectually demanding functions can be more easily executed over the internet, in a long term, this fact should be reflected in a growing proportion of e-working. To study this assumption, we examine adopting e-working within selected thirty-five countries. Research questions were formed as follows: Is there a demonstrable influence of favorable PISA results on the overall rates of e-working in certain states? Is it possible to sustain different components with e-working? Can appropriate eworking legislation contribute to the overall rates of e-working at a state's level? Our study adopted Spearman's Rho correlation using 4 numerical variables to measure the strength of association between pairs of variables - the proportion of e-working and four country's PISA averages in Mathematics, Science, Reading and Financial Literacy. Its results indicate a positive correlation: the probability of e-working increases with the PISA results growth. Further, Qualitative Content Analysis was used. Based on our data e-working will not go away and it is time to update law on e-working. Governments should formalize rights and duties. Face-to-display work is likely to be an unstoppable evolution at workplace. These components affected higher eworkability. These results draw attention to how e-working is becoming major element in common life with some challenges and difficulties and that we need to study these two influencer factors in order to optimize its arrangements.
\end{abstract}

\section{Keywords:}

E-working;

PISA Results;

Legislation;

Correlation;

Qualitative Content Analysis.

\section{Article History:}

$\begin{array}{llll}\text { Received: } & 17 & \text { February } & 2021 \\ \text { Revised: } & 29 & \text { April } & 2021 \\ \text { Accepted: } & 06 & \text { May } & 2021 \\ \text { Published: } & 01 & \text { June } & 2021\end{array}$

\section{1- Introduction}

The detachment of work from place is a growing trend [1] but e-working progressed slowly and unevenly before the Covid-19 explosion [2]. Dingel and Neiman (2020) [3] suggest unequal opportunity impacting some industries and regions while leaving others unscathed. The growth rose on both part-time and full-time basis, hybrid or fully. Suddenly, the pandemic shut down businesses and schools. The hygienic regulations implemented social distancing to workforce and students. Some of them have thrived in this face-to-display situation, others have struggled and some still continue to struggle. Similarly, some parents have embraced remote learning, while others remain concerned about their children's education and emotional well-being.

A recent JRC study provides a rough estimate of around $25 \%$ of employment in teleworkable sectors in the EU as a whole [4]. E-working situations depend directly on the industry and specific job requirements allowing completing the assigned tasks. Data show that in Australia 41\% of full-time and 35\% of part-time jobs can be done from home [5].

Hatayama et al. (2020) [6] findings indicate the amenability of jobs to working from home increases with the level of economic development of the country. Middle-income countries see the largest declines as they feature a relatively large share of employment in non-essential sectors and a relatively low work-from-home ability [7]. Additionally, an

\footnotetext{
*CONTACT: Beno@mail.vstecb.cz
}

DOI: http://dx.doi.org/10.28991/esj-2021-01277

(C) 2021 by the authors. Licensee ESJ, Italy. This is an open access article under the terms and conditions of the Creative Commons Attribution (CC-BY) license (https://creativecommons.org/licenses/by/4.0/). 
IMF study highlights the dependency between the level of economic development and the ability to work remotely. This suggests that workers in emerging and developing economies could face daunting challenges in continuing to work during periods of hard lockdowns [8]. Further findings indicate that the extent to which jobs are amenable or responsive to being done from home increases with the level of economic development of the country [9]. It seems that, in general, countries with higher GDP per capita also tend to have a higher share of teleworkable jobs [10]. Nicholas (2009) [11] found that the level of education had a significant association with an interest in e-working: "Partial support was found for the effect of autonomy and work/life balance toward the preference to telework." Men were more interested in teleworking than women [11]. Anghel et al. (2020) [12] emphasize that not all workers are going to be able to take advantage of e-working arrangements since those with a lower level of educational attainment will find it difficult to be able to benefit from them. Possibly, they miss direct instruction and control because the 2018 Future Workforce Report says that "nearly $63 \%$ of companies today have remote workers, yet a majority lack remote work policies" [13]. Prior the hit of the pandemic, e-working was relatively unusual in European Union and therefore largely unregulated.

At the same time, Seneca said: "Luck is what happens when preparation meets opportunity." Based on his quote, one can estimate that countries with more relevant education and legislation were prepared better and struggled less. As a result, the effect of e-working on education and legislation received limited attention. The main goal of this paper was to examine the conditions for the successful implementation and expansion of e-working within selected countries. First, we study whether the PISA (Program for International Student Assessment) 2018 results relate to the spread of face-todisplay work. In particular, the correlations of e-working intensity with the PISA subjects were used to find answers to the following research questions: Is there a demonstrable influence of favourable PISA results on the overall rates of eworking in certain states? Is it possible to sustain different components with e-working?

Then, Qualitative Content Analysis (QCA) was used to find an answer to the next question: Can appropriate eworking legislation contribute to the overall rates of e-working at a state's level?

The second section provides an account of the concept of e-working. The third one outlines the methodology used in this research. The fourth section gives a short overview of our results and the ways to them. Then a section presenting our discussion and research limitations follows. The last one presents conclusions.

\section{2- E-working: Conceptual Framework}

Telecommuting was first introduced by Jack M. Nilles in 1970s [14]. The main driver was then to let employees save costs of commuting to work [14-15]. Later, working at home was linked with the savings of gasoline [16]. In this vein, Zhang et al. (2020) [17] affirm telework as the traffic demand management policies to mitigate congestion during rush hours and decrease work-related trips. Recent paper work discusses the potential advantages and disadvantages of eworking [18]. E-working is not only economically essential (triple win option [18]) it is a helpful tool in Covid-19 times and future pandemics. Similarly, latest data indicate a positive acceptance of work-from-home concept by the people [19].There is still no uniform definition of teleworking/telecommuting. The classic definitions of teleworking are outdated being too narrow or explicit [20]. There are broader approaches of this kind of work, some requiring specific regularity and location, while others are fairly traditional about regularity and location. The concept of ICT (information and communications technology) enabled work from afar or telework, also known as remote work, virtual work or telecommuting [21]. "Since the idea of telecommuting has been around for decades now, it makes sense that new words and phrases would come to replace what is, in theory, a not-so-new workplace concept" [22]. Beno and Hvorecky (2021) [23] describe e-working concept as method of working by making use of ICT technology in a situation in which the work is not bound to any particular location.

We define e-working as performing job-related activities outside the office premises using the electronic data transfer to the head office, customers or business partners. According to Nilles (1994) [24] telework includes more than just working at home and communicating with the office via telecommunication tools, for example working in work centers (an office area for employees from several companies) in the teleworkers neighborhood or in satellite offices (office of the company located in an area where there is a concentrated number of its teleworkers). Kurkland and Bailey (1999) [25] define the four different teleworking types as follows: (1) The Home Office, (2) The Satellite Office, (3) The Neighborhood Work Center and (4) Mobile Working. Thus, face-to-display work can be located at any distance from headquarters, work center, during a travel or in the virtual world.

There are four factors that influence telework [26]: individual factors, job factors, organizational factors, and family/home factors. Belzenegui-Eraso and Erro-Carcés [27] add technology because technology infrastructure is necessary while e-working. Different authors pay different attention to them. The War for Talent [28] changed how companies manage talent worldwide because the skilled talents are a critical driver for corporate performance. The rise of e-working in this way relates to low unemployment, especially of knowledge workers [29]. The rising costs of living with no additional value play their role, too [30]. The increasing commuting distance is the next element. In 2018, more than 1 in 5 European workers will spend 90 minutes or more of their time on their way to and from work. On average, European workers spend 1 hour and 24 minutes a day commuting, travelling $28.56 \mathrm{~km}$ in total [31]. 70\% of Europeans 
think their commute has a strong ecological footprint with the cars being the kings of the commute [32]. Moreover, Millennials are growing up [33], moving out and boomeranging back [34]. As stated by Beno and Ferencikova (2019) [33] technology, global changes, globalization and Generations $\mathrm{Y}$ and Z have an immense influence on the employment picture, which is changing very fast.

\section{3- Research Methodology}

Figure 1 presents the flowchart of the research methodology used in this study. Our research is based on processing secondary data and deriving relevant conclusions.

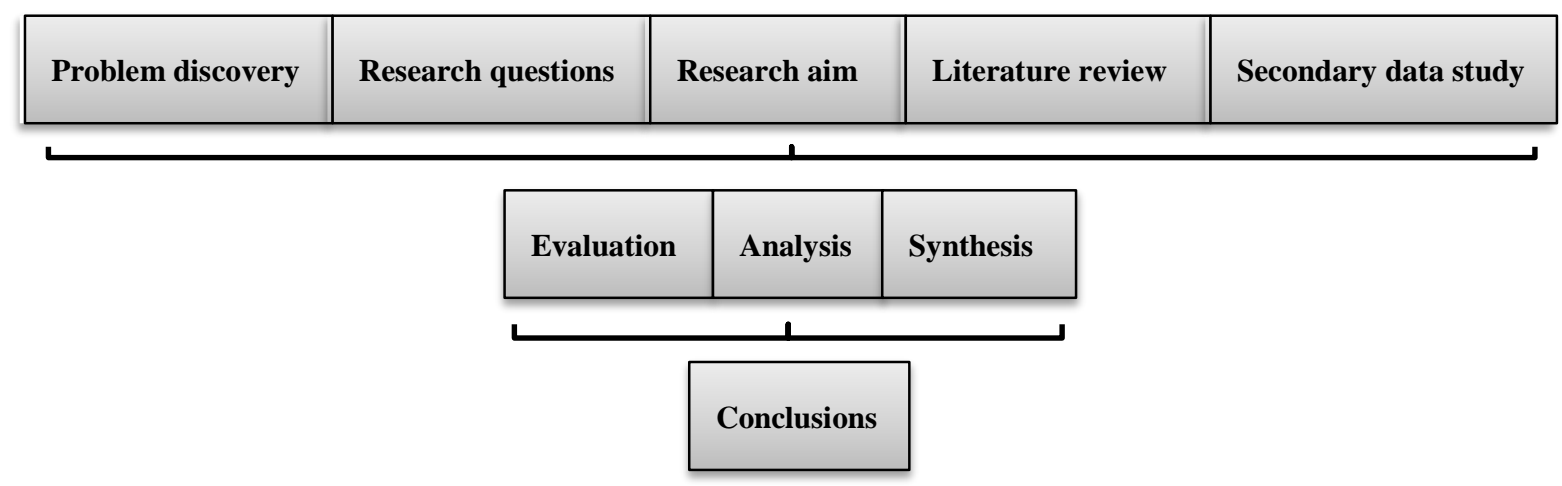

Figure 1. Flow chart of the research methodology.

The descriptive statistics method was used to analyse and to describe the basic features of the data in developing results and drawing conclusions, and the information processed in Table 1 was identified and summarised. Examined data in cross-tabulation between categorical variables of e-working in 2018 [2] and Pisa results from 2018 [35] were evaluated. Financial Literacy was not tested in all surveyed countries due to its voluntary character.

Table 1. E-working Ratio (2018) and PISA Results (2018).

\begin{tabular}{|c|c|c|c|c|c|}
\hline Country & E-working in \% & Mathematics & Science & Reading & Financial literacy \\
\hline Austria & 10.0 & 499 & 490 & 484 & \\
\hline Belgium & 6.6 & 508 & 499 & 493 & \\
\hline Bulgaria & 0.3 & 436 & 424 & 420 & 432 \\
\hline Croatia & 1.4 & 464 & 472 & 479 & \\
\hline Cyprus & 1.2 & 451 & 439 & 424 & \\
\hline Czechia & 4.0 & 499 & 497 & 490 & \\
\hline Denmark & 7.8 & 509 & 493 & 501 & \\
\hline Estonia & 7.6 & 523 & 530 & 523 & 547 \\
\hline Finland & 13.3 & 495 & 493 & 493 & 537 \\
\hline France & 6.6 & 495 & 493 & 493 & \\
\hline Germany & 5.0 & 500 & 503 & 498 & \\
\hline Greece & 2.0 & 451 & 452 & 457 & \\
\hline Hungary & 2.3 & 481 & 481 & 476 & \\
\hline Iceland & 6.5 & 495 & 475 & 474 & \\
\hline Ireland & 6.5 & 500 & 496 & 518 & \\
\hline Italy & 3.6 & 487 & 468 & 476 & 476 \\
\hline Latvia & 2.9 & 495 & 487 & 479 & 501 \\
\hline Lithuania & 2.5 & 481 & 482 & 476 & 498 \\
\hline Luxembourg & 11.0 & 483 & 477 & 470 & \\
\hline Malta & 5.8 & 472 & 457 & 448 & \\
\hline Montenegro & 6.4 & 430 & 415 & 421 & \\
\hline Netherlands & 14.0 & 519 & 503 & 485 & \\
\hline North Macedonia & 1.9 & 394 & 413 & 393 & \\
\hline Norway & 5.5 & 501 & 490 & 499 & \\
\hline Poland & 4.6 & 516 & 511 & 512 & 520 \\
\hline Portugal & 6.1 & 492 & 492 & 492 & 505 \\
\hline
\end{tabular}




\begin{tabular}{clllll} 
Romania & 0.4 & 430 & 426 & 428 & \\
Serbia & 3.3 & 448 & 440 & 439 & 444 \\
Slovakia & 3.6 & 486 & 464 & 458 & 481 \\
Slovenia & 6.9 & 509 & 507 & 495 & \\
Spain & 4.3 & 481 & 483 & 506 & 492 \\
Sweden & 5.3 & 502 & 499 & 506 & \\
Switzerland & 4.1 & 515 & 495 & 484 & \\
Turkey & 2.2 & 454 & 468 & 466 & \\
United Kingdom & 4.4 & 502 & 505 & 504 & \\
\hline
\end{tabular}

To determine the existence of dependency between e-working and individual dimensions, Spearman's rank-order (nonparametric) correlation was applied measuring the strength and direction of relationship between two ranked variables. To disclose these potential correlations, answers to the next research questions were sought: Is there a demonstrable influence of favorable PISA results on the overall rates of e-working in certain states? Is it possible to sustain different components with e-working?

In the next step, we applied a qualitative content analysis (QCA) to find an answer for next research question: Can appropriate e-working legislation contribute to the overall rates of e-working at a state's level? There are many definitions of QCA. For the purpose of the current paper, we apply the QCA definition being "the systematic reduction of content, analysed with special attention to the context in which it was created, to identify themes and extract meaningful interpretations of the data" [36]. We have looked for a relationship between higher positions in the e-working saturation and the presence of legal guidance of countries where such legislation was introduced prior to the pandemic.

\section{4- Findings}

\section{4-1- Correlations Results}

The purpose of conducting this analysis was to prove the different rate of e-working in the surveyed thirty-five countries and the e-workability of each component. Table 2 shows Spearman's Rho correlations that test relationships among the study variables.

Table 2. Correlations results

\begin{tabular}{|c|c|c|c|c|c|c|}
\hline & & Mathematics & Science & Reading & Financial literacy & $\%$ e-working \\
\hline \multirow{3}{*}{ Mathematics } & Correlation Coefficient & 1.000 & $0.926 * *$ & $0.813^{* *}$ & $0.886 * *$ & $0.624 * *$ \\
\hline & Sig. (2-tailed) & --- & 0.000 & 0.000 & 0.000 & 0.000 \\
\hline & $\mathrm{N}$ & 34 & 34 & 34 & 11 & 34 \\
\hline \multirow{3}{*}{ Science } & Correlation Coefficient & $0.926 * *$ & $1.000 * *$ & $0.898 * *$ & $0.973 * *$ & $0.595 * *$ \\
\hline & Sig. (2-tailed) & 0.000 & --- & 0.000 & 0.000 & 0.000 \\
\hline & $\mathrm{N}$ & 34 & 35 & 35 & 11 & 35 \\
\hline \multirow{3}{*}{ Reading } & Correlation Coefficient & $0.813^{* *}$ & $0.898 * *$ & $1.000^{* *}$ & $0.870^{* *}$ & $0.544 * *$ \\
\hline & Sig. (2-tailed) & 0.000 & 0.000 & --- & 0.000 & 0.001 \\
\hline & $\mathrm{N}$ & 34 & 35 & 35 & 11 & 35 \\
\hline \multirow{3}{*}{ Financial Literacy } & Correlation Coefficient & $0.886^{* *}$ & $0.973 * *$ & $0.870^{* *}$ & $1.000^{* *}$ & $0.761 * *$ \\
\hline & Sig. (2-tailed) & 0.000 & 0.000 & --- & 0.000 & 0.007 \\
\hline & $\mathrm{N}$ & 11 & 11 & 11 & 11 & 11 \\
\hline \multirow{3}{*}{$\%$ e-working } & Correlation Coefficient & $0.624 * *$ & $0.595 * *$ & $0.544^{* *}$ & $0.761 * *$ & $1.000 * *$ \\
\hline & Sig. (2-tailed) & 0.000 & 0.000 & 0.001 & 0.007 & --- \\
\hline & $\mathrm{N}$ & 34 & 35 & 35 & 11 & 35 \\
\hline
\end{tabular}

** Correlation is significant at the 0.01 level (2-tailed).

An overview of results data reveal moderate strong positive correlation (data marked in yellow). It means that link is strong, those data are linked and increase together. Austria, Belgium, Denmark, Estonia, Finland, France, Germany, Iceland, Ireland, Malta, Norway, Portugal, Slovenia and Sweden are seen to provide better performers in the triennial PISA, therefore higher rates of e-working (over 5\%). This also confirms data from US News of Best Countries for Education [37]. Interestingly, the US News Best Countries list ranks United Kingdom an overall \#2 for Education, but has lower (4.4\%) ratio of e-working. Mas and Pallais [38] emphasize that college graduates have a $28 \%$ point higher rate of homework. The higher education system experienced significant changes [39]. Technological advances and competitiveness resulted to workforce being available anytime [40-42]. Similarly to Abulibdeh (2020) [43] who emphasize that the difference in adopting and implementing teleworking between countries is the differences in technology (digital divide) and the economic characteristics (postindustrial, industrial, transitional, or developing) of these countries. Obviously, low adoption of ICT, low rates of educational attainment [44-45] is linked in adaptation of e-working practices. 
Our data confirm the statement of Anghel et al. (2020) [12] that higher education means higher share of e-workers. Further research confirms that higher-paying jobs that require more education have a higher capacity to become remote jobs, highlighting concerns about inequality [46]. Lund et al. [47] found that the potential for remote work is highly concentrated among highly skilled, highly educated workers in a handful of industries, occupations, and geographies. Education level also has a high impact on a worker's likelihood of working from home. Based on recent data, "among 25 and over, those with an advanced degree were more likely to work at home than were persons with lower levels of educational attainment, $42 \%$ of those with an advanced degree performed some work at home on days worked, compared with $12 \%$ of those with a high school diploma and no college [48]." In pre-Covid time, remote work in America was a luxury reserved for just $7 \%$ of the workforce, mostly highly educated and highly paid knowledge workers [49]. Recent study discovers that those who are not able to carry out their work duties remotely are more likely to lose their occupation [50]. Yasenov [51] further adds that immigrants, younger adults, and those who are with lower levels of education are less likely to do their tasks remotely.

Romans' [52] perspective to Covid-19 pandemic time is viewed as an option to activate students perception about the world they live in, its interlinking, and consider a myriad of questions to help young people to recognize and evaluate the potential impacts they might see from a community that works and educates itself remotely. The educational sector has been impacted by Covid-19 at all levels, from preschool to tertiary education [43].

\section{4-2- Qualitative Content Analysis}

Since the outbreak of Covid-19 pandemic, many employers and employees have converted to full-time or hybrid (partly remote and partly in the office) e-worker status. Some of them still remain in that status in which fully in-person and e-work will be two ends of a fluid spectrum of work options and anticipate continuing working remotely. In some cases, e-working employees' homes are in different jurisdictions than their assigned offices. Numerous employers are more likely to have e-workers who live in different states. In other words, taking inventory of each e-worker and the jurisdictional implications for each state involved.

Before discussing the legal issues related to e-working, a global survey found that Finland, Sweden, Australia, Thailand, New Zealand, the Netherlands, Switzerland, the United Kingdom, the United States and Ireland were offering highest workplace flexibility [53]. Legislative approaches to workplace flexibility vary across countries [54]. In Table 3 we summarized some of the important Flexible working policies (FWP) for regular employees in Europe.

Table 3. Flexible working policies for regular employees.

\begin{tabular}{|c|c|c|}
\hline Country & FWP & $\begin{array}{c}\text { E-working } \\
\%\end{array}$ \\
\hline Finland & $\begin{array}{l}\text { Working Hours Act }(\mathbf{6 0 5} / \mathbf{1 9 9 6}) \text { has empowered Finns to adjust their working day by starting or finishing } \\
\text { up to three hours earlier or later [55]. }\end{array}$ & $13 \%$ \\
\hline Netherlands & $\begin{array}{l}\text { Flexible Work Act (2016): Employees with at least } 26 \text { weeks of service who work for a company of } 10+ \\
\text { employees have the right to ask for a change, increase, or decrease in their working hours as well as the } \\
\text { ability to work from another location [56]. }\end{array}$ & $14 \%$ \\
\hline Norway & $\begin{array}{l}\text { Working Environment Act (2006) establishes the right to flexible working hours if this can be arranged } \\
\text { without major inconvenience to the employer [57]. }\end{array}$ & $5 \%$ \\
\hline Italy & $\begin{array}{l}\text { Legge 22, n.81 (2017) regulates "smart working (lavoro agile)" and establishes the equality of workers } \\
\text { performing the same duties, even if done remotely [58]. }\end{array}$ & $3.6 \%$ \\
\hline Luxembourg & $\begin{array}{l}\text { Two main legal sources: A framework agreement at European level (2002) and A Grand Ducal } \\
\text { Regulation of } 15 \text { March } 2016 \text { making mandatory the agreement by and between the social partners [59]. }\end{array}$ & $11.0 \%$ \\
\hline United Kingdom & $\begin{array}{l}\text { The Fair Work Act (2009): All employees that have worked for the same employer for at least } 26 \text { weeks } \\
\text { may "make a statutory application" for flexible working [60]. }\end{array}$ & $4.4 \%$ \\
\hline
\end{tabular}

In Table 3 we present countries which started building their legislative support prior to the pandemic. Its middle column indicates the year when the law was published and its outline. The right column shows the proportion of eworking (copied from Table 1). The median of the particular column in Table 1 is 4.6. With the exception of Italy, all countries are above the median. Possible explanation is "managerial culture" as stated by Durieu. She further explains than in the Nordic or Anglo-Saxon countries, including Belgium, cultivate management by objective. In Latin and Eastern countries, a culture of the face-to-face work is preferred. In other words managers have the impression that employees do not work if managers do not have them in front of them [61]. 
Nordic countries (Finland, Denmark and Sweden) have a legacy of encouraging work-life balance and flexible working policies [62]. Finland has always been ahead of the flexible working policies among European countries. It passed a law in 1996 requiring companies to provide their employees with a start time and end time that is flexible within three hours to accommodate family and personal obligations. Due new Working Hours Act which came into force in 2020, gave the majority of full-time employees the right to decide when and where they work for at least half of their working hours [63]. Finnish economy survived the coronavirus crisis better than expected [64] and a million Finns started working from home like it is business as usual [65].

As for many countries, different European countries have recently seen a marked increase in the number of e-workers as part of social distance and curb the Covid-19 pandemic. As the Covid-19 crisis makes a pressure on governments, there are legal initiatives that will likely increase the proportion of e-working after the pandemic end.

Germany desires to offer employees a legal right to work from home [66]. With the new law, which is in the drafting process, Germany wants to legalize that right to work remotely and enact regulations to bring structure to this new and at-times nebulous way of working $[67,68]$.

In Spains' Royal Decree-law 28/2020 [69] are still some areas where the decree does not provide the level of detail and clarity that employers might reasonably expect to help them to implement these arrangements in practice. First key aspect is its definition. Further, the main thrust of the decree is to require remote working arrangements to be formalized through written agreements. Second key aspect is voluntariness. The decree makes clear that remote working must be voluntary for the employee and that any refusal to work remotely will not justify the termination of that individual's employment. The law applies only remote working that is carried out on a regular basis. Remote working will only be "regular" if over any three months at least 30\% of the employee's total hours are carried out remotely. Third key aspect is the equal rights as face-to-face workers. Remote employees shall have the right to exercise their collective rights as the rest of the employees.

Additionally, the rule concerning hardware has changed. While, in the case of regular teleworking, the employer is still obliged to provide an employee with tools needed for the job (an internet connection, for example) hybrid solutions may be decided in the case of exceptional practice (less than $10 \%$ of the annual time), to avoid doubling costs. The right for the employer to inspect the workplace of his employee, considered invasive, has been abolished. The newest laws is neither a right, nor an obligation, but remains on voluntariness [70].

\section{5- Discussion}

E-working has been broadly adopted globally during the pandemic. The spread of relevant legislation indicates that trend will remain a key component of the post-pandemic workplace. To follow Seneca's suggestion, all country parliaments should examine promptly whether it is actually subject to potential jurisdiction for legal claims in each state where it has an e-employee. The question is whether they can equally fast also facilitate their education systems to support the same direction.

Our data show that education and rate of e-working correlate. Finland scores for a high educated population, is one of the top performers in PISA, has one of the highest e-working rates. Some countries follow the Finns' way but most European countries do not. Still, there is a rather strong positive correlation in Mathematics and Science. The Reading skills are also supportive but not as big as the previous ones. The relation to Financial Literacy seems to be the strongest one. Unfortunately, the number of countries is not sufficient for building a strong argument.

Let us revert to the questions: Will we think differently about online learning? Will online learning be proactive Trojan horse for university-business collaboration? [71]. Based on Clancy [72] those with the skills to work in the knowledge economy largely reside in cities, since that is where the jobs are. To skill up the kind of people who would most benefit from remote work, we need to offer online degree programs. The author further emphasize that the kinds of students who excel at online education are more likely to excel as remote workers too [72]. The next question is, would move to more e-working enable others to spend more time differently? Can the resources that will be saved by having fewer offices be invested back into education? And how much money would be saved? Recent study stress that firms expect working from home to triple [73].

Will e-working become the norm? On a regular basis or not occasionally? At home or any other place? Will the next world be built outside the cubicles? Sectors that do not require the employee's physical presence have combatively adopted e-working in knowledge-intensive sectors and in industries with well-understood processes. Germany is going to introduce of a minimum of 24 days of Home office [74]. Change has been made also in Spain where the culture of eworking was almost absent before Covid-19. In Austria Home office rules will be presented in March 2021 [75]. In many countries around the world, the Covid-19 health crisis has prompted a rethinking of the implementation of eworking, often with reservations despite the health situation. Full-time employees were allowed to carry out their tasks from home. But there are concerns that the shift away from the salaryman model will experience problems [76]. Generally, it is still a long way to go to make e-working a universal rule. 


\section{6- Conclusions}

The main research questions investigated in this paper are:

RQ1: Is there a demonstrable influence of favourable PISA results on the overall rates of e-working in certain states? Is it possible to sustain different components with e-working?

Data reveal moderate positive correlation. It means that relationship is present, the studied data are linked and increase together. Austria, Belgium, Denmark, Estonia, Finland, France, Germany, Iceland, Ireland, Malta, Norway, Portugal, Slovenia and Sweden are seen to provide better performers in the triennial PISA, therefore higher rates of e-working.

RQ2: Can appropriate e-working legislation contribute to the overall rates of e-working at a state's level?

Yes, Nordic countries (Finland, Denmark and Sweden) have a legacy of encouraging work-life balance and flexible working policies. Moreover, the countries posing their legal standards soon will occupy position in the higher half of ranking.

Whether motivated by higher productivity, employees' well-being, cost reductions, health issues or other motives almost every industry will adopt Face-to-Display work but the question remains when. Currently, the pandemic is forcing every industry to adopt some form of flexibility, not always leading to the best results. Sometimes employee morale suffers. Other times the process performance suffers. Authors of the paper see education as the best tool to combat anti-face-to-display policies. Generally, some of the education system has years of experience in optimizing distance education with know how it works and how to do it. Authors stress that these experiences of online education managing provide some insight into the potential of e-working.

Just like online learning, e-working means giving up daily interactions with people who are working in the same position. In higher education, we have seen that for some types of students (especially for adult working professionals), combined (onsite and online) learning and solely online learning is preferred as only possibility to complete or continue courses or education. For some students, such as recent high-school graduates, an experience of learning and living in campus is preferential. Education especially online learning gives students greater flexibility in what classes they can take, when they can take them, and where they have to be in order to take them. Compared to face-to-face to face-todisplay discussions through available ICT those interactions can take still place. As with education, e-working may not be most appropriate solution for every occupation. It depends on skills, sort of work and who is doing it.

Also, the cultivation of management by objective seems to play its role here. In other words, managers' impression that employees do not work if they do not have them in front of them seems to be reverting. It is time to update laws on e-working policy. Can other countries implement Finland's e-working best example? In few words, a new ecosystem is needed to create best in class working environment and education.

Contributions in this paper work can lead to new lines of inquiry in the area of e-working and education. Several new questions emerge: Disruption in work environment and education accelerated by Covid-19 but is there more work to be done? How education and e-working may go best in class? Both work and education's new normal will be hybrid, more virtual?

This research has so far highlighted some limitations. Firstly, we are considering only linear relationships. There may be variables other than $x$ that have not been studied, yet do influence the response variable. A strong correlation does not necessarily only imply a cause and effect relationship. Moreover, it is the generality of the findings in correlational research. Further, Spearman's rank correlation is not as precise as the common method. This is due to the fact that all the information concerning the data is not utilized. Finally, missing data of financial literacy from other countries for building strong arguments.

\section{7- Declarations}

\section{7-1-Author Contributions}

M.B. conceived of the presented idea, was engaged in the investigation, literature search and selection, verified the analytical methods, writing original draft, preparation, and finishing the last version. J.H. was involved in proof reading and contribution to the last version. All authors discussed and derived the results and contributed to the final manuscript.

\section{7-2-Data Availability Statement}

The data presented in this study are available on request from the corresponding author.

\section{7-3- Funding}

The authors received no financial support for the research, authorship, and/or publication of this article. 


\section{7-4- Conflicts of Interest}

The authors declare that there is no conflict of interests regarding the publication of this manuscript. In addition, the ethical issues, including plagiarism, informed consent, misconduct, data fabrication and/or falsification, double publication and/or submission, and redundancies have been completely observed by the authors.

\section{8- References}

[1] Felstead, Alan, and Golo Henseke. "Assessing the growth of remote working and its consequences for effort, well-being and work-life balance.” New Technology, Work and Employment 32, no. 3 (October 04, 2017): 195-212. doi:10.1111/ntwe.12097.

[2] Eurostat, Databrowser, Employed persons working from home as a percentage of the total employment, by sex, age and professional status (\%), Available online: https://ec.europa.eu/eurostat/databrowser/view/lfsa_ehomp/default/table?lang=en (accessed on 21 December 2020).

[3] Dingel, Jonathan I., and Brent Neiman. “How Many Jobs Can Be Done at Home?” Journal of Public Economics 189 (September 2020): 104235. doi:10.1016/j.jpubeco.2020.104235.

[4] Fana, Marta, Songul Tolan, Sergio Torrejón Perez, Maria Cesira Urzi Brancati, and Enrique Fernández-Macías; "The Covid confinement measures and EU labour markets", Luxembourg: EUR 30190EN, Publications Office of the European Union, (2020). doi:10.2760/079230.

[5] Teleworkability in Australia: $41 \%$ of full-time and $35 \%$ of part-time jobs can be done from home, Available online: $\mathrm{http} / /$ theconversation.com/teleworkability-in-australia-41-of-full-time-and-35-of-part-time-jobs-can-be-done-from-home140723 (accessed on 21 December 2020).

[6] Jobs' Amenability to Working from Home, Evidence from Skills Surveys for 53 Countries, Available online: http://documents1. worldbank.org/curated/en/673341589224762491/pdf/Jobs-39-Amenability-to-Working-from-Home-Evidence-from-SkillsSurveys-for-53-Countries.pdf (accessed on 21 December 2020).

[7] Gottlieb, Charles, Jan Grobovsek, Markus Poschke, and Fernando Saltiel. “Lockdown Accounting.” IZA, (2020).

[8] Who will Bear the Brunt of Lockdown Policies? Evidence from Tele-workability Measures across Countries, Available online: https://www.imf.org/en/Publications/WP/Issues/2020/06/12/Who-will-Bear-the-Brunt-of-Lockdown-Policies-Evidence-fromTele-workability-Measures-Across-49479 (accessed on 21 December 2020).

[9] Hatayama, Maho, Mariana Viollaz, and Hernan Winkler. "Jobs' amenability to working from home: Evidence from skills surveys for 53 countries." World Bank Policy Research Working Paper 9241 (2020).

[10] Working in Times of Pandemic: Only one in five workers in LAC can actually work from home, Available online: https://www. latinamerica.undp.org/content/rblac/en/home/presscenter/director-s-graph-for-thought/working-at-a-distance--the-availabilityof-teleworkable--jobs-an0.html (accessed on 21 December 2020).

[11] Nicholas, Arlene. "Millennial Interest in Teleworking: A survey of generational attitudes.” VDM Verlag Dr. Müller (2009).

[12] Anghel, Brindusa, Marianela Cozzolino, and Aitor Lacuesta. "Teleworking in Spain.” SSRN Electronic Journal (2020). doi: 10.2139/ssrn.3678038.

[13] Upwork, New report finds majority of companies are embracing remote teams, yet more than half lack a remote work policy, Available online: https://www.upwork.com/press/releases/future-workforce-report-2018 (accessed on 22 December 2020).

[14] Nilles, M. Jack, Paul Gray, Roy F. Carlson, and Gerhad J. Hanneman. “Telecommunications -Transportation Tradeoff.” National Science Foundation (1974).

[15] Nilles, Jack M. “Telework: Enabling Distributed Organizations.” Information Systems Management 14, no. 4 (January 1997): 7-14. doi:10.1080/10580539708907069.

[16] Working at Home Can Save Gasoline, Available online: https://www.washingtonpost.com/archive/opinions/1979/09/02/ working-at-home-can-save-gasoline/ffa475c7-d1a8-476e-8411-8cb53f1f3470/ (accessed on 22 December 2020).

[17] Zhang, Shihang, Rolf Moeckel, Ana Tsui Moreno, Bin Shuai, and Jie Gao. "A Work-Life Conflict Perspective on Telework." Transportation Research Part A: Policy and Practice 141 (November 2020): 51-68. doi:10.1016/j.tra.2020.09.007.

[18] Beňo, Michal. "The Advantages and Disadvantages of E-Working: An Examination Using an ALDINE Analysis." Emerging Science Journal 5 (April 19, 2021): 11-20. doi:10.28991/esj-2021-sper-02.

[19] Dubey, Akash Dutt, and Shreya Tripathi. "Analysing the Sentiments towards Work-From-Home Experience during COVID-19 Pandemic.” Journal of Innovation Management 8, no. 1 (April 28, 2020). doi:10.24840/2183-0606_008.001_0003.

[20] Beno, Michal. "Transformation of Human Labour from Stone Age to Information Age." Lecture Notes in Computer Science (2018): 205-216. doi:10.1007/978-3-319-97163-6_17. 
[21] Gajendran, Ravi S., and David A. Harrison. "The Good, the Bad, and the Unknown About Telecommuting: Meta-Analysis of Psychological Mediators and Individual Consequences.” Journal of Applied Psychology 92, no. 6 (November 2007): 15241541. doi:10.1037/0021-9010.92.6.1524.

[22] Million for Work Flexibility, Remote Work or Telecommute: What's the Difference, Available online: https://www. workflexibility.org/remote-work-vs-telecommute-whats-the-difference/ (accessed on 21 December 2020).

[23] Beno, Michal, and Jozef Hvorecky. "Data on an Austrian Company's Productivity in the Pre-Covid-19 Era, During the Lockdown and After Its Easing: To Work Remotely or Not?” Frontiers in Communication, 6, (2021): 46. doi:10.3389/fcomm.2021.641199.

[24] Nilles, M. Jack. "Making Telecommuting Happen: A Guide for Telemanagers and Telecommuters.” Van Nostrand Reinhold (1994).

[25] Kurkland, Nancy B., and Diane E. Bailey. "The Advantages and Challenges of Working Here, There Anywhere, and Anytime." Organizational Dynamics 28, no. 2 (1999): 53-68. doi:10.1016/s0090-2616(00)80016-9.

[26] Baruch, Yehuda, and Nigel Nicholson. "Home, Sweet Work: Requirements for Effective Home Working." Journal of General Management 23, no. 2 (December 1997): 15-30. doi:10.1177/030630709702300202.

[27] Belzunegui-Eraso, Angel, and Amaya Erro-Garcés. "Teleworking in the Context of the Covid-19 Crisis." Sustainability 12, no. 9 (May 1, 2020): 3662. doi:10.3390/su12093662.

[28] Chambers G. Elisabeth, Mark Foulon, Helen Handfield-Jones, Steven M. Hankin, and Edward G. Michaels III. "The War for Talent.” The McKinsey Quarterly, 3, no. 3, (1998): 44-57.

[29] CBS, Knowledge migration in the Netherlands and Europe, Available online: https://www.cbs.nl/en-gb/custom/2020/07/ knowledge-migration-in-the-netherlands-and-europe (accessed on 22 December 2020).

[30] Numbeo, Cost of Living Index by Country 2020 Mid-Year, Available online: https://www.numbeo.com/cost-of-living/rankings _by_country.jsp?title=2020-mid\&displayColumn=0 (accessed on 22 December 2020).

[31] SD Worx, More than 20\% of Europeans Commute at Least 90 Minutes Daily, Available online: https://www.sdworx.com/en/ press/2018/2018-09-20-more-than-20percent-of-europeans-commute-at-least-90-minutes-daily (accessed on December 2020).

[32] SD Worx, Nearly three-quarters of European employees think their commute has a good ecological footprint, Available online: https://www.sdworx.com/en/press/2019/2019-09-10-nearly-three-quarters-of-european-employees-think-their-commute (accessed on 07 December 2020).

[33] Beno Michal, and Sona Ferencikova. "The Future of Work is e-Work.” 14th IWKM 2019, (November, 2019): 6-20.

[34] U.S. Bureau of Labor Statistics; Independence for young millennials: moving out and boomeranging back, Available online: https://www.bls.gov/opub/mlr/2014/article/independence-for-young-millennials-moving-out-and-boomeranging-back.htm (accessed on 07 December 2020).

[35] The Program for International Student Assessment (PISA); PISA 2018 U.S. Results, Available online: https://nces.ed.gov/ surveys/pisa/pisa2018/pdf/PISA2018_compiled.pdf (accessed on 21 December 2020).

[36] Roller, Margaret R., and Paul J. Lavrakas. “Applied qualitative research design: A total quality framework approach.” The Guilford Press (2015).

[37] US. News Best Countries for Education, Available online: https://www.usnews.com/news/best-countries/best-education (accessed on 22 December 2020).

[38] Mas, A., and Amanda P., Alternative Work Arrangements, Available online: https://scholar.harvard.edu/files/pallais/files /alternative_work_arrangements_01.pdf (accessed on 22 December 2020).

[39] Mudrak, Jiri, Katerina Zabrodska, Petr Kveton, Martin Jelinek, Marek Blatny, Iva Solcova, and Katerina Machovcova. “Occupational Well-Being among University Faculty: A Job Demands-Resources Model.” Research in Higher Education 59, no. 3 (July 13, 2017): 325-348. doi:10.1007/s11162-017-9467-x.

[40] Melin, Marika, Wanja Astvik, and Claudia Bernhard-Oettel. "New Work Demands in Higher Education. A Study of the Relationship between Excessive Workload, Coping Strategies and Subsequent Health among Academic Staff." Quality in Higher Education 20, no. 3 (September 2, 2014): 290-308. doi:10.1080/13538322.2014.979547.

[41] Saltmarsh, Sue, and Holly Randell-Moon. "Managing the Risky Humanity of Academic Workers: Risk and Reciprocity in University Work-life Balance Policies." Policy Futures in Education 13, no. 5 (April 15, 2015): 662-682. doi:10.1177/1478210315579552.

[42] Ng, Cheuk Fan. "Academics Telecommuting in Open and Distance Education Universities: Issues, Challenges and Opportunities." The International Review of Research in Open and Distributed Learning 7, no. 2 (September 28, 2006). doi:10.19173/irrodl.v7i2.300. 
[43] Abulibdeh, Ammar. “Can COVID-19 Mitigation Measures Promote Telework Practices?” Journal of Labor and Society 23, no. 4 (November 18, 2020): 551-576. doi:10.1111/wusa.12498.

[44] Chinn, Menzie D., and Robert W. Fairlie. "ICT Use in the Developing World: An Analysis of Differences in Computer and Internet Penetration.” Review of International Economics 18, no. 1 (February 2010): 153-167. doi:10.1111/j.14679396.2009.00861.x.

[45] Dewan, Sanjeev, Dale Ganley, and Kenneth L. Kraemer. "Complementarities in the Diffusion of Personal Computers and the Internet: Implications for the Global Digital Divide.” Information Systems Research 21, no. 4 (December 2010): 925-940. doi:10.1287/isre.1080.0219.

[46] Harvard Business School Working Knowledge, How Much Will Remote Work Continue after the Pandemic, Available online: https://hbswk.hbs.edu/item/how-much-will-remote-work-continue-after-the-pandemic (accessed on 22 December 2020).

[47] McKinsey \& Company, What's next for remote work: An analysis of 2,000 tasks, 800 jobs, and nine countries, Available online: https://www.mckinsey.com/featured-insights/future-of-work/whats-next-for-remote-work-an-analysis-of-2000-tasks-800-jobsand-nine-countries (accessed on 22 December 2020).

[48] U.S. Bureau of Labor Statistics, American Time Use Survey Summary, Available online: https://www.bls.gov/news. release/atus.nr0.htm (accessed on 22 December 2020).

[49] The Trade-Offs of Remote Work, Available online: https://www.aei.org/wp-content/uploads/2020/11/The-Trade-Offs-ofRemote-Work.pdf (accessed on 22 December 2020).

[50] Adams-Prassl, Abi, Teodora Boneva, Marta Golin, and Christopher Rauh. Inequality in the impact of the coronavirus shock: Evidence from real time surveys, Available online: https://www.inet.econ.cam.ac.uk/working-paper-pdfs/wp2018.pdf (accessed on 03 May 2021).

[51] Yasenov, I. Vasil. Who can work from home?, Available online: https://papers.ssrn.com/abstract=3590895 (accessed on 03 May 2021).

[52] Roman, T. Harry. "Classroom Challenge: Work-at-Home Challenge." Technology and Engineering Teacher, 80, no. 1 (2020): 26-27.

[53] EHS Today, Finland, Sweden, Australia Offer Most Flexible Work Schedules, Available online: https://www.ehstoday.com /archive/article/21904410/finland-sweden-australia-offer-most-flexible-work-schedules (accessed on 22 December 2020).

[54] Hegewisch, Ariane. Flexible working policies: a comparative review. Manchester: Equality and Human Rights Commission, 2009.

[55] Ministry of Employment and the Economy, Finland, Working Hours Act (605/1999), Available online: https://www.finlex.fi/ en/laki/kaannokset/1996/en19960605_20100991.pdf (accessed on 22 December 2020).

[56] Wet flexible werken, Available online: https://puc.overheid.nl/mp-bundels/doc/PUC_33018_10/20160101/ (accessed on 22 December 2020).

[57] Lovdata, Act relating to working environment, working hours and employment protection, etc. (Working Environment Act), Available online: https://lovdata.no/dokument/NLE/lov/2005-06-17-62\#KAPITTEL_3 (accessed on 22 December 2020).

[58] Misure per la tutela del lavoro autonomo non imprenditoriale e misure volte a favorire l'articolazione flessibile nei tempi e nei luoghi del lavoro subordinato, L. 22 maggio 2017, n. 81, Available online: https://www.cliclavoro.gov.it/Normative/Legge-22maggio-2017-n81.pdf (accessed on 22 December 2020).

[59] Conventiondu 20 October 2020 relative $\mathrm{Au}$ Regime Juridique Du Teletravail, Available online: https://uel.lu/wpcontent/uploads/2020/10/2020-10-20-teletravail-convention-ogbl-lcgb-uel.pdf (accessed on 24 December 2020).

[60] Gov.uk, Employing people, Contracts of employment and working hours, Flexible working, Available online: https://www. gov.uk/flexible-working (accessed on 22 December 2020).

[61] Archyde, "The work of tomorrow": will teleworking become the norm?, Available online: https://www.archyde.com/the-workof-tomorrow-will-teleworking-become-the-norm/ (accessed on 23 December 2020).

[62] Nordic Council of Ministers, Flexible work arrangements: The Nordic Gender Effect at Work, Available online: http://norden.diva-portal.org/smash/get/diva2:1240047/FULLTEXT02.pdf (accessed on 23 December 2020).

[63] LKOS Law, Legal Update, Working Hours Act, Available online: https://www.lkoslaw.fi/legal-update-working-hours-act/ (accessed on 23 December 2020).

[64] Open Insights by Nordea, Finland: Round one victory over coronavirus, Available online: https://insights.nordea.com/ en/economics/finnish-economic-outlook-sep2020/ (accessed on 23 December 2020).

[65] Business Finland, Is Finish Workforce The Most Covid-19 Resilient In The World?, Available online: https://www.businessfinland.fi/en/whats-new/news/invest-in-finland/2020/is-finnish-workforce-the-most-covid-19-resilient-inthe-world/ (accessed on 23 December 2020). 
[66] Süddeutsche Zeitung $\mathrm{GmbH}$, Der tiefe Eingriff in die Arbeitswelt ist längst passiert, Available online: https://www.sueddeutsche.de/meinung/homeoffice-recht-heil-1.5055019 (accessed on 24 December 2020).

[67] Stellungnahme Nr. 74/2020, November 2020, Available online: https://brak.de/zur-rechtspolitik/stellungnahmenpdf/stellungnahmen-deutschland/2020/november/stellungnahme-der-brak-2020-74.pdf (accessed on 24 December 2020).

[68] Referentenentwurf des Bundesministeriums für Arbeit und Soziales, Available online: https://www.brak.de/w/files/newsletter_ archiv/berlin/2020/2020_589anlage.pdf (accessed on 24 December 2020).

[69] Boletín Oficial Del Estado, Real Decreto-ley 28/2020, de 22 de septiembre, de trabajo a distancia, Available online: https://www.boe.es/boe/dias/2020/09/23/pdfs/BOE-A-2020-11043.pdf (accessed on 24 December 2020).

[70] Conventiondu 15 Decembre 2015 Relative Au Regime Juridique Du Teletravail, Available online: http://data.legilux.public.lu /file/eli-etat-leg-memorial-2016-45-fr-pdf.pdf (accessed on 24 December 2020).

[71] Hvorecký, Jozef, Michal Beňo, and Renata Janošcová. “Online Education as an Integral Part of Universities’ Strategy.” INTED2021 Proceedings, International Technology, Education and Development Conference, (March 2021): 5197-5205. doi: 10.21125/inted.2021.1066.

[72] Clancy, Matthew, "The Case for Remote Work" (2020). Economics Working Papers: Department of Economics, Iowa State University. 20007. Available online: https://lib.dr.iastate.edu/econ_workingpapers/102 (accessed on 24 December 2020).

[73] Federal Reserve Bank of Atlanta, Firms Expect Working from Home to Triple, Available online: https://www.frbatlanta.org/ blogs/macroblog/2020/05/28/firms-expect-working-from-home-to-triple (accessed on 24 December 2020).

[74] ZDF, Heil will 24 Tage Anspruch auf Homeoffice, Available online: https://www.zdf.de/nachrichten/wirtschaft/homeofficeheil-anspruch-24-tage-100.html (accessed on 24 December 2020).

[75] Diepresse, Homeoffice-Regelung kommt erst im März 2021, Available online: https://www.diepresse.com/5869268/homeoffice -regelung-kommt-erst-im-marz-2021 (accessed on 24 December 2020).

[76] Deutsche Welle, Coronavirus: Is working from home becoming the new normal in Japan?, Available online: https://www. dw.com/en/coronavirus-is-working-from-home-becoming-the-new-normal-in-japan/a-53740957 (accessed on 24 December 2020). 